\title{
Plate Interactions, Evolving Magmatic Styles, and Inheritance of Structural Paths: Development of the Gold-Rich, Miocene EI Indio Epithermal Belt, Northern Chile
}

\author{
ROBERTO OYARZUN, ${ }^{1}$ \\ Departamento de Cristalografía y Mineralogía, Facultad de Ciencias Geológicas, Universidad Complutense, \\ 28040 Madrid, Spain \\ JAVIER LILLO, \\ Escuela Superior de Ciencias Experimentales y Tecnología, Universidad Rey Juan Carlos, Tulipán s/n, \\ 28933 Móstoles (Madrid), Spain \\ JORGE OYARZUN, \\ Departamento de Minas, Facultad de Ingeniería and CEAZA, Universidad de La Serena, Casilla 554, La Serena, Chile
}

AND PABlo Higueras

Departamento de Ingeniería Geológica y Minera, Escuela Universitaria Politécnica de Almadén, Universidad de Castilla-La Mancha, Plaza M. Meca 1, 13400 Almadén, Spain

\begin{abstract}
Ore deposits constitute singularities in the Earth crust, and form in response to a combination in time and space of a variety of geological processes. We here explore the complex setting that led to formation of an outstanding belt of precious-metal epithermal deposits in northern Chile, including the world class Au-Cu-As El Indio deposit. We discuss the formation of the El Indio belt in terms of Oligocene-Miocene plate tectonic and magmatic evolution of the Nazca-South America margin. The analysis of Landsat images allows recognition of a highly fractured domain involving a major Oligocene NW-SE-trending fault zone, with associated $\mathrm{R}_{1}-\mathrm{R}_{2}$-type structures. We suggest that a set of time-coincidental factors that occurred between $\sim 10$ and 6 Ma may have led to formation of the Late Miocene El Indio belt. Late Miocene subduction of the Juan Fernández Ridge (JFR) coincided with a substancial shift in magmatic emplacement style, linked to a compositional change from andesitic to dacitic, which resulted in the passage from stratovolcanoes to dome and dike complexes. It is not the composition alone, but the style that may be the crucial element here to understand why mineralization developed. Although stratovolcanoes easily vent volatiles and metals (via violent eruptions and quiescent outgassing), intrusions tend to retain these, and therefore, can generate volatile-, metal-rich hydrothermal solutions. We further propose that subduction of the JFR may have involved increased plate coupling, and the reactivation of older NNE trending $R_{2}$ type shears (inherited structural corridors), along which the belt would have formed preferentially.
\end{abstract}

\section{Introduction}

ORE DEPOSITS, especially the important ones, are anomalous features in the Earth crust, and this explains why an unusual combination of geologic processes is required to form them. If this is true for a single occurrence, imagine what it takes to form an entire belt of ore deposits. We suggest that it was a very unusual combination of Miocene events in northern Chile (Coquimbo Region) that allowed for-

${ }^{1}$ Corresponding author, e-mail: oyarzun@geo.ucm.es mation of the El Indio belt (Fig. 1). The Coquimbo region is located in northern Chile and is one of the richest in mineral deposits (Fig. 1). The Andean realm of this region hosts one of the most spectacular belts of hydrothermal alteration zones, including economic gold deposits of the epithermal type. Among these we highlight the world-class El Indio $\mathrm{Au}-\mathrm{Cu}$-As deposit (Fig. 1). The belt formed during Late Miocene time (Bissig et al., 2002a), and most of the alteration zones and deposits in the Coquimbo Region occur along a relatively narrow NNE-trending corridor (Figs. 1 and 2). We here discuss the 


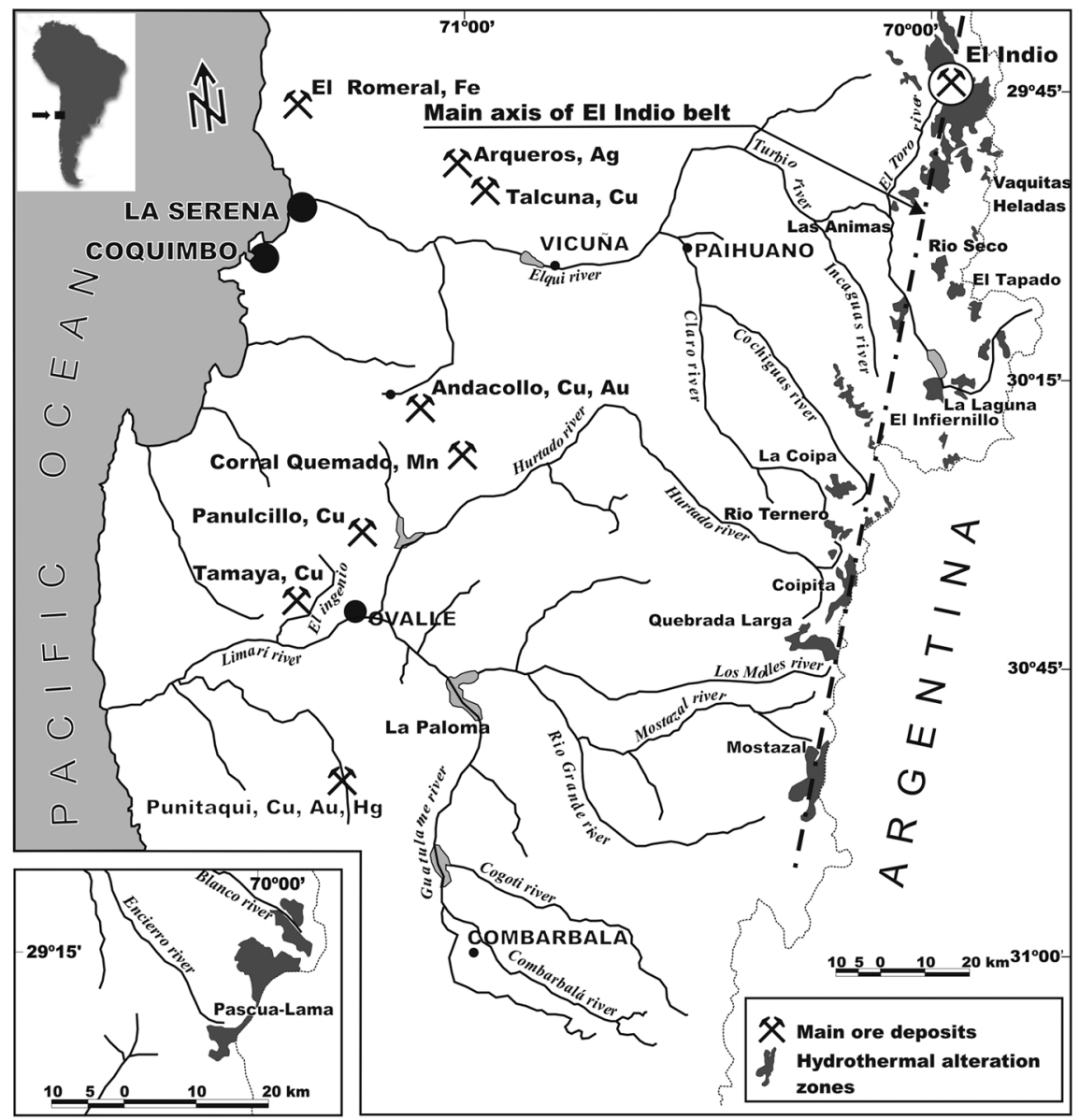

FIG. 1. The Coquimbo region, northern Chile and location of major mineral deposits and alteration zones. Location of ore deposits and hydrothermal alteration zones after Maksaev et al. (1984) and Higueras et al. (2004).

regional structural lineaments present in the Andes of the Coquimbo region, and offer an interpretation in terms of the development of an evolving structural scenario characterized by the presence of a large $\mathrm{NW}$-SE-trending fault zone and associated $\mathrm{R}_{1}$ and $\mathrm{R}_{2}$ type structures of probable Oligocene age (Oyarzun et al., 2006). We suggest that the epithermal belt may have formed along reactivated $R_{2}$ shears (structural corridors), during a major shift in Late Miocene magmatism.

\section{Geology and Mineral Deposits}

The geology of the Coquimbo region can be divided into two contrasting domains. A western zone comprising: (1) Miocene to Pliocene marine sediments that crop out along a narrow coastal belt (Le Roux et al. 2006); and (2) Lower Cretaceous volcanic and sedimentary rocks (Aguirre and Egert, 1965; Boris, 1985; Rivano and Sepulveda, 1991) hosting stratabound and vein-type $\mathrm{Cu}$ deposits, $\mathrm{Ag}$ vein-type deposits, $\mathrm{Cu}-\mathrm{Hg}-\mathrm{Au}$ vein-type deposits, and Mn stratabound deposits (Talcuna, Arqueros, Punitaqui, and Corral Quemado districts; Oyarzun et al. 1998; Higueras et al., 2004); epithermal gold and porphyry copper deposits (Andacollo district; Oyarzun et al. 1996); and Kiruna-type iron deposits (El Romeral; Oyarzun et al. 2003) (Fig. 1). The Lower Cretaceous rocks were intruded by granitoids of mid-Cretaceous age. The stratigraphic sequence of the western domain is overlain by Upper Cretaceous andesites and clastic sediments and by Lower 
Tertiary basaltic to rhyolitic rocks (Aguirre and Egert, 1965). The high-altitude (Andean) eastern domain is more complex, comprising units that range in age from Paleozoic to Pliocene (Maksaev et al., 1984). The Paleozoic units include DevonianCarboniferous pelites and sandstones and Upper Paleozoic rhyolites, breccias, tuffs, and andesites. Granitoids include those of the Elqui-Limari and Incaguas batholiths (Carboniferous). Mesozoic rocks include Triassic andesites and sandstones; Lower Jurassic limestones, sandstones, and shales; Upper Jurassic-Cretaceous sandstones, tuffs, and rhyolites; and Upper Jurassic conglomerates, sandstones, andesites, breccias, and tuffs. From the metallogenic point of view, the Cenozoic is the most relevant time span, and comprises the following units (Maksaev et al. 1984): the Doña Ana Formation (Upper Oligocene-Lower Miocene; rhyolites, tuffs, and basaltic andesites), the Infiernillo unit (Lower Miocene; granites, granodiorites, monzodiorites, and andesite porphyries), the Cerro de las Tórtolas Formation (Lower to Middle Miocene; andesites, tuffs, agglomerates, and ignimbrites), and the Vallecito Formation (Upper Miocene; andesites, tuffs, agglomerates, and ignimbrites).

More than 30 large alteration zones of Miocene age can be defined along the high Andes within a belt of $\sim 200 \times 20 \mathrm{~km}$ (Atacama and Coquimbo regions) (Maksaev et al., 1984). The Coquimbo segment of the belt is NNE oriented, and comprises zones of alteration such as (Figs. 1 and 2): El Indio, Vaquitas Heladas, La Animas, Rio Seco, El Tapado, La Laguna, El Infiernillo, La Coipa, Rio Ternero, Coipita, Quebrada Larga, and Mostazal (Maksaev et al., 1984). Many of the El Indio belt alteration zones comprise advanced argillic alteration mineral assemblages, with kaolinite, alunite, and silica jaspers. The Miocene history of hydrothermal processes in this realm is long and complex, although mineralization took place at the specific time span of 9.4-6.2 Ma (Bissig et al., 2002a). Volcaniclastic facies of the Doña Ana Formation constitute the most typical altered rocks along the belt, although older units have been also affected by the hydrothermal processes.

The most conspicuous deposit along the belt is the world-class El Indio (e.g., Maksaev et al., 1984; Araneda, 1985; Siddeley and Araneda, 1986). El Indio (Araneda, 1985) is a vein-type deposit (tensional fractures) bound by NNE-SSW faults, thus defining a $500 \mathrm{~m}$ long, $100-150 \mathrm{~m}$ wide mineralized corridor. The deposit is hosted by volcaniclastic rocks of the Tilito Member of Doña Ana Formation (rhyolitic to dacitic welded tuffs). The deposit (before mining) hosted two types of veins. (1) Gold-quartz (up to $6 \mathrm{~m}$ thick), with native gold and calaverite, enargite, and tetrahedrite-tennantite, with some chalcopyrite, sphalerite, and galena in depth. Cu grades were in the range of 1 to $5 \%$ and mean gold grades were of $240 \mathrm{~g} \mathrm{t}^{-1}$, although localized sectors exceeded these concentrations up to more than 1,000 $\mathrm{g} \mathrm{t}^{-1}$ (and $86 \mathrm{~g} \mathrm{t}^{-1} \mathrm{Ag}$ ). (2) Massive sulfide veins (up to $12 \mathrm{~m}$ thick) with enargite, pyrite, and minor chalcopyrite and tetrahedrite-tennantite. $\mathrm{Cu}$ grades were in the range of 8-14\%, whereas those of gold and silver ranged from $8-10 \mathrm{~g} \mathrm{t}^{-1}$ and 140-160 $\mathrm{g} \mathrm{t}^{-1}$, respectively. Alteration assemblages include those of the advanced argillic alteration (quartz-pyrophyllite, alunite), together with phyllic and propylitic mineral aseemblages, and silicification.

The nearby El Tambo deposit constitutes a different case, characterized by the presence of hydrothermal breccias with clasts of dacitic tuffs cemented by silica, barite, and alunite. Au and silver grades were in the ranges of 7-22 and 1-54 $\mathrm{g} \mathrm{t}^{-1}$, respectively. Although the Pascua-Lama epithermal deposit is located farther north, in the Atacama Region (Fig. 1), and is displaced slightly westward with respect to the main NNE trend, it also deserves attention because of the size and present economic importance. Despite some initial environmental concerns, the mining project will become fully operational in the next few years. Reserves are estimated at $225 \mathrm{Mt}$, grading $1.98 \mathrm{~g} \mathrm{t}^{-1} \mathrm{Au}, 66 \mathrm{~g} \mathrm{t}^{-1} \mathrm{Ag}$, and $0.05 \% \mathrm{Cu}$ (Chouinard et al., 2005). The ore is hosted by Triassic granites and Miocene breccia pipes.

\section{Major Structural Lineaments: An Interpretation}

Lineaments may correspond to the superficial expression of ancient, deep-crustal, or trans-lithospheric structures (Richards, 2000). Salfity (1985) was one of the first to recognize the importance of major NW-SE and NE-SW lineaments in northern Chile-Argentina. These major structural trends are oblique to the main Andean direction (N-S) and their age is unknown. Richards (2000) related the occurrence of porphyry copper deposits in northern Chile to the intersection of some of these lineaments with the West Fissure Zone. While inspecting a Landsat image of the region (LANDSAT 7 ca. 2000; 


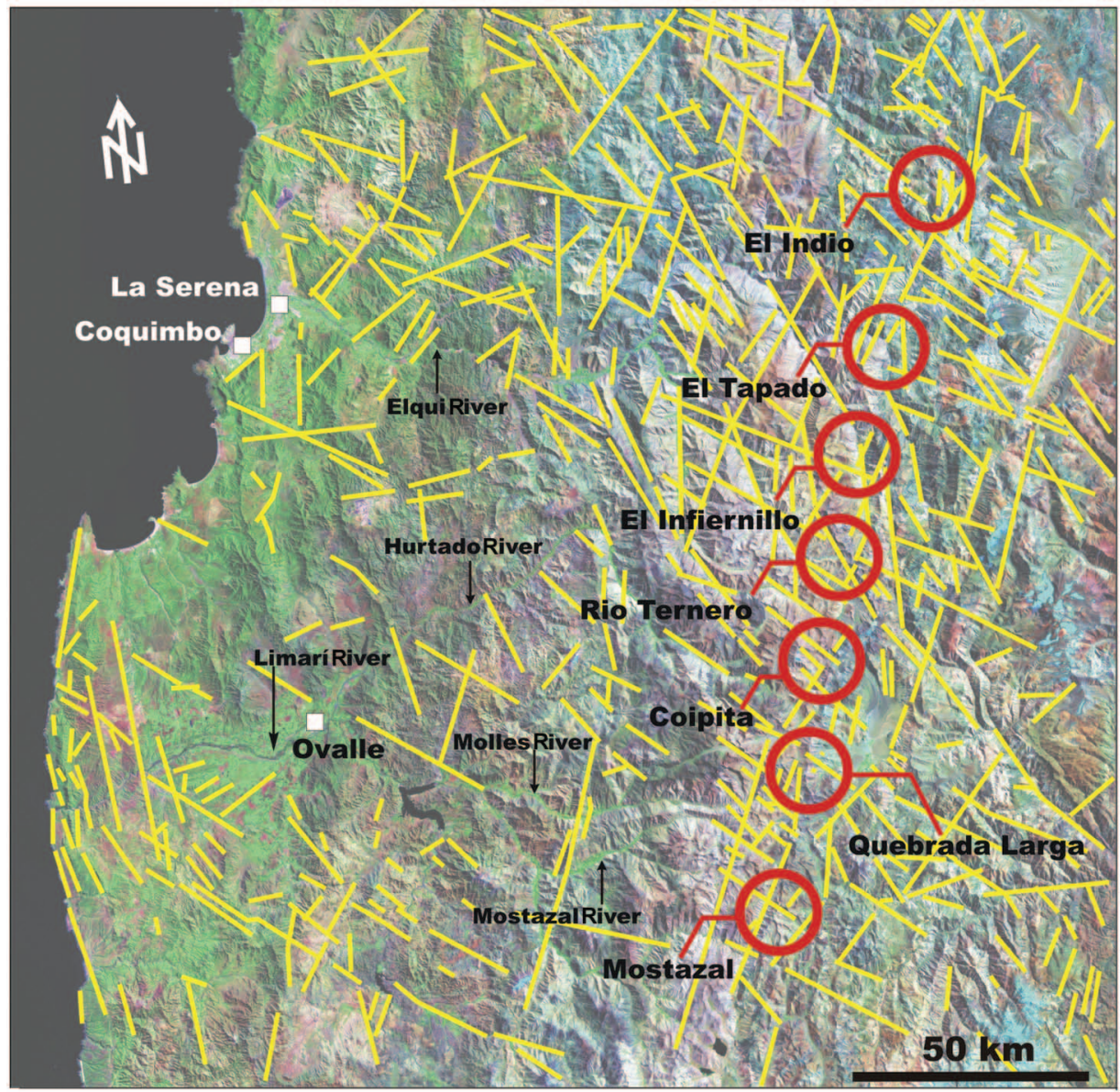

$\square$ Town

Structural lineament

Hydrothermal alteration zone

FIG. 2. LANDSAT 7 image including approximate location of some of the main alteration zones, prospects, and epithermal ore deposits (red circles), and major structural lineaments (yellow lines). For interpretation of the structural lineaments, see Figure 3.

Orthorectified Landsat Enhanced Thematic Mapper Bands 7, 4, 2), we found striking evidence for a major zone of deformation trending NW-SE, with associated NNE-SSW and NE-SW structures (Fig. 2 ), very much resembling fault development within shear zones (Fig. 3A). However, to generate a shear zone of this size and orientation, plate interactions must be strong and geometrically consistent to induce such a shearing. In other words, a roughly $\mathrm{N}-\mathrm{S}$-oriented stress field would be required to generate a major fault zone of such type and orientation. In this case, the fault zone would be dextral and the NNE-SSW and NE-SW structures would represent $R_{1}$ and $R_{2}$ (Riedel 1 and 2 ) type structures. These, together with the inferred $\mathrm{P}$ and $\mathrm{Y}$ shears, constitute common shears found within brittle fault zones (e.g., Passchier and Trouw 1998).

The main objection to this idea comes from the present convergence between Nazca and South America, which is roughly oriented ENE. However, some clues for the understanding of the geodynamic setting of this realm can be found in the time-span of 28-20 Ma, a major turning point for the evolution of the Farallon-Nazca-South America system. Between chrons $10(28.26 \mathrm{Ma})$ and $8(25.81 \mathrm{Ma})$ the Chile Ridge rotated from $\mathrm{E}-\mathrm{W}$ to $\mathrm{N} 40^{\circ} \mathrm{W}$, a rotation that continued between chron 8 and chron 6 (20.16 Ma), from $\mathrm{N} 40^{\circ} \mathrm{W}$ to $\mathrm{N}-\mathrm{S}$ (Tebbens and Cande, 1997). It 
A

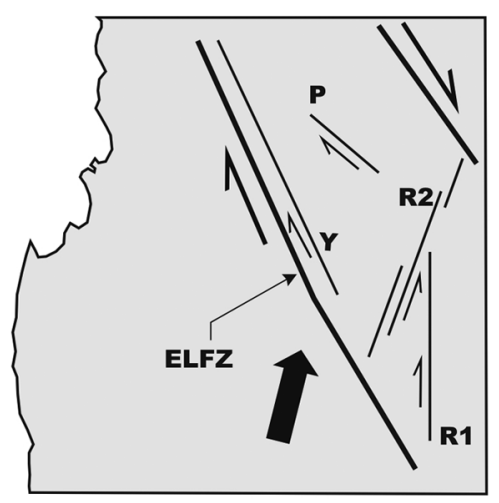

Development of a large fault zone (ELFZ), intense fracturing

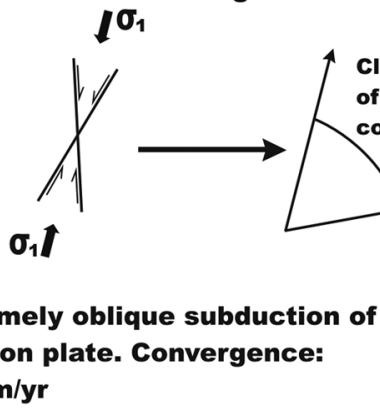

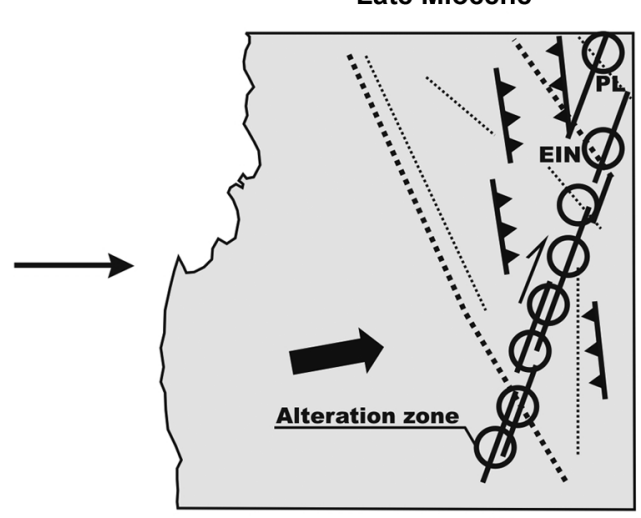

Reactivation of old R2 structures, reverse faulting. EIN: EI Indio, PL: Pascua-Lama

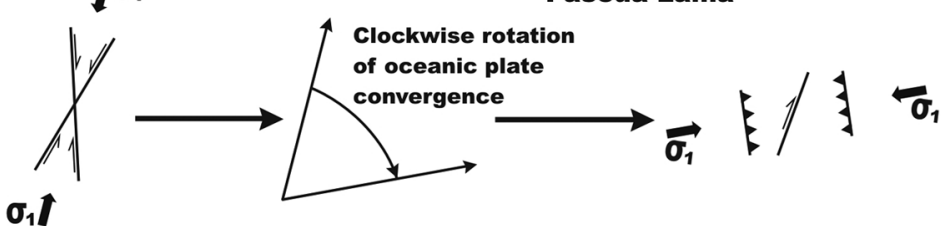

\section{Oblique and flat subduction of Nazca plate. Subduction of JFR. Uplifting ( 10-6 Ma). Formation of EI Indio Belt. Convergence: $\sim 10 \mathrm{~cm} / \mathrm{yr}$}

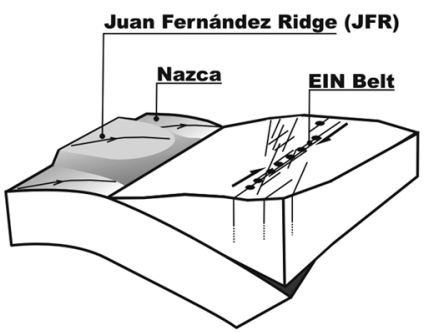

FIG. 3. A. Structural interpretation of lineaments in terms of a NW-SE fault zone (ELFZ) and tectonic evolution from Late Oligocene to Late Miocene. PYR-type structures after (sensu) Passchier and Trouw (1998). ELFZ = Elqui-Limarí fault zone: EIN = El Indio; PL = Pascua-Lama. B. Plate tectonic evolution during the same time span, from Farallon to Nazca and structural emplacement of the El Indio belt. EIN = El Indio.

is during this time span that Farallon was broken into small plates including Nazca (in its southern realm), involving a change from extremely oblique (Farallon-South America) to almost perpendicular (Nazca-South America) convergence. In this respect, by Late Oligocene time, subduction was rapid and NNE directed (Cande and Leslie, 1986;
Tebbens and Cande, 1997), which would have provided adequate geodynamic conditions to trigger major dextral NW-SE shearing at the regional scale (Figs. 3A and 3B).

Besides, as shown by the geology of the Pascua-Lama sector, this process may have been enhanced and facilitated by the structural fabric of 


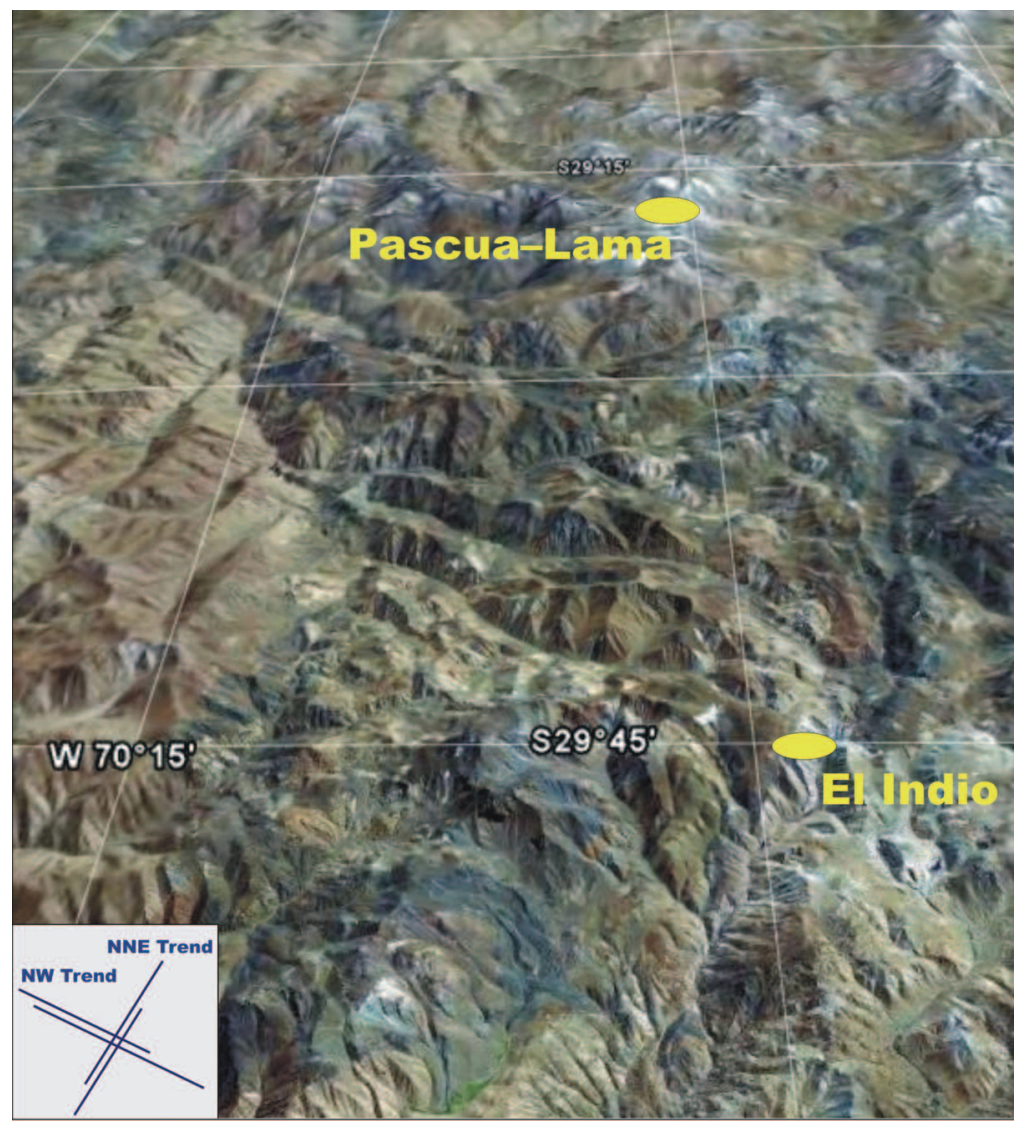

FIG. 4. NW and NNE trends, and location of El Indio and Pascua-Lama deposits. The two deposits are separated by a distance of $\sim 58 \mathrm{~km}$. Google Earth oblique image.

the basement rocks (Chouinard et al., 2005). The inferred zone of deformation in the Coquimbo region could have been active by Oligocene time, and has been named as the Elqui-Limarí fault zone (ELFZ) (Oyarzun et al., 2006). Given the clockwise rotation of the convergence vector of the Nazca-Farallon plate from Late Oligocene time onward (from NNE to ENE directed; Fig. 3A), movement along the major trend of the ELFZ must have gradually declined. However, old structures, large and small, can be reactivated if an adequate new stress field develops. Thus, we suggest that the NNE set (Fig. 4) could have been easily reactivated during Miocene time in response to the ENE-directed compression derived from the mildly oblique subduction of the Nazca plate (Fig. 3A). As discussed later, other tectonic processes such as increased plate coupling and block uplifting by Late Miocene time, may have decisively contributed to the reactivation of these structures.

\section{The Nazca Plate-Juan Fernández Ridge Factor: A Late Miocene Tectonic, Magmatic, and Metallogenic Scenario}

Despite almost continuous magmatic activity during Late Oligocene-Middle Miocene time (Doña Ana, Infiernillo, and Cerro de las Tórtolas units), no mineralization developed along the present El Indio belt. In fact, as shown by the comprehensive work of Bissig et al. (2002a), mineralization along the belt was concentrated in a relatively short period during Late Miocene time. A key question to be answered is what makes this time span different. The Miocene history of hydrothermal processes in this realm was in fact long lived (Bissig et al., 2002a), including 
barren events at 13.6-10.0 Ma, and a main episode of mineralization at 9.4-6.2 Ma. Bissig et al. (2002a) suggested that the barren premineralization episodes in the main districts developed before incision of the pediment, whereas mineralization took place during formation of the major Los Ríos surface. However, can erosion-morphology coupled to subsequent changes in the near surface hydrodynamic system explain barren versus mineralizing events? In this regard, we believe that pediplain formation may have indeed contributed to the process. However, it cannot be regarded as the sole cause, and therefore other factors should be also considered in order to understand the why, when, and where the epithermal belt formed.

The $\sim 10$ to $6 \mathrm{Ma}$ time span is a turning point in many aspects in the Atacama and Coquimbo regions. As indicated by Yáñez et al. (2002), oceanic plate subduction underneath a continent is a first-order process driving the tectonic and magmatic evolution of mountain belts. Furthermore, changes in the regional tectonic style of the overriding plate are largely related to variations in slab deep and convergence obliquety (Yáñez et al. 2002). As explained above, the Oligocene to Miocene transition in central and northern Chile was controlled by the breakup of the Farallon plate, and the passage from extremely (NNE directed) to mildly oblique (ENE directed) subduction (Fig. 3B). According to Kay and Mpodozis (2002), both termination of andesitic arc volcanism at $\sim 9 \mathrm{Ma}$, and the shallowing of the slab coincide with the arrival and progressive subduction of the Juan Fernández Ridge (Fig. 3B). At $\sim 10 \mathrm{Ma}$, the JFR reached the present coordinates of the Coquimbo region. Although the Late Oligocene-Early Miocene is characterized by basaltic to andesitic volcanism within intra-arc basins, the 10-8 Ma interval marked the transition from andesitic stratovolcanic centers to isolated dacitic dome complexes (Kay and Mpodozis, 2002). Besides, all volcanism in the Coquimbo region ended with the eruption of the dacitic Vallecito Formation ignimbrites at 6 to 5 Ma.

A recent paper on sedimentation controlled by regional crustal behavior (Le Roux et al., 2006) highlights some crucial aspects regarding evolution of the Coquimbo region. According to these authors, subduction of the JFR (Fig. 3B) would have resulted in crustal uplifting from 10.5 to $6.9 \mathrm{Ma}$. This episode was followed by subsidence until $2.1 \mathrm{Ma}$, when new uplifting began. This last tectonic process coincides with renewed magmatism (Cerro de Vidrio rhyolitic dome), which was emplaced at $\sim 2.0 \mathrm{Ma}$ near to the Pascua-Lama deposit (Bissig et al, 2002b).

Thus, it seems clear that the time span $\sim 10$ to 6 Ma was remarkable in tectonic, magmatic, and metallogenic terms in the region under study. On one side this time period coincides with the subduction of the Juan Fernández Ridge, the flattening of subduction, and crustal uplifting. Besides, intra-arc andesitic volcanism disappears and is replaced by dacitic magamtism, as dome and/or dike dacitic complexes. Last but not least, it is precisely during this period of time, when mineralization events take place along the El Indio belt (Bissig et al., 2002a). A key issue to be analyzed is how these "time-coincidental" factors relate each other. Kay and Mpodozis (2002) comprehensively explained the cause-effect relationships between the subduction of the JFR and the change in magmatic style in northern and central Chile. However, can a shift in magmatism alone explain the origin of the $\mathrm{Au}-\mathrm{Cu}$ epithermal mineralization? Perhaps we need another element in this unsolved puzzle.

As explained above, the Coquimbo segment of the El Indio belt occurs along a well-defined NNE trend. We provide some clues for the understanding of this trend, that is, in terms of the reactivation of $\mathrm{R}_{2}$-type structures belonging to the older ELFZ (Fig. $3 \mathrm{~A})$. However, the question is, how these $R_{2}$-type structures would reactivate, and specifically, why during the time span under consideration. If an oceanic ridge and associated volcanic plateaus start subduction, we must expect some tectonic changes in the overriding plate. So far we have explored two possibilities: magmatism and crustal uplifting. However, there is a third one not yet mentioned: faulting. In this respect we suggest that positive evidence is provided by the active margin of Panama, where significant strike-slip faulting in this region (e.g., the Azuero-Sona fault) may have been facilitated by increased plate coupling due to subduction of the elevated Coiba Ridge (MacMillan et al., 2004).

We may now have some key elements to advance a few proposals regarding the El Indio belt, and in this respect we suggest the following schematic model. (1) By Late Miocene time, the Juan Fernández Ridge started subduction in the area under study (Fig. 3B). (2) Increased plate coupling resulting from this subduction reactivated older $\left(R_{2}\right.$-type $)$ structures (Fig. 3A). Moreover, strong erosion leading to pediplain formation (Bissig et al., 2002a) could have helped the process in the following way: 
the unloading of structural blocks by strong erosion would have led to isostatic rebound, in other words, to fault-controlled uplifting of blocks. (3) Block movement could easily have been accommodated by normal faulting (in this case, with a strike-slip component), which in turn would have favored the emplacement of magma bodies, and circulation of hydrothermal fluids. (4) A magmatic shift from andesitic to dacitic (domes, stocks, dikes) took place, and these complexes become preferentially emplaced along inherited structural corridors defined by the older (reactivated) NNE-trending structures. At the more local scale (prospect/clusters of prospects), the older NW-SE trend of faults also may have contributed to the emplacement of intrusive complexes (providing an inactive, however fractured, structural domain), and we do not discard the interplay of both sets in terms of the intersection of highly fractured structural corridors (Fig. 4). Furthermore, sectors where the density of fracturing was increased by deformation would have become permeability nodes for the migration of hydrothermal fluids, which eventually may have led to formation of large zones of alteration and mineral precipitation (Tripp and Vearncombe, 2004). (5) Last but not least, given the Late Miocene dominant style of magmatism (subsurface magma emplacement with minor or no associated volcanism), volatiles would not be easily vented via main volcanic edifices, and therefore could have been increasingly available to enrich the hydrothermal fluids (e.g., Pasteris, 1996; Oyarzun et al. 2001). As shown by Yang and Scott (2005), magmas provide large quantities of metals and volatiles to hydrothermal systems. However, volcanism is constantly venting volatiles, and this occurs either by violent and massive introduction of volcanic aerosols to the atmosphere (e.g., Rampino and Self, 1992), or quiescent degassing (e.g., Matsumoto and Hinkley, 2001).

An important aspect to be considered here is the type of magma involved in the eruptive process (e.g., Oyarzun et al., 2005). Given that intermediate to acid magmas are more viscous and richer in water than the mafic ones, the eruptions are more violent, and therefore can lead to the direct introduction of ash and volatiles into the stratosphere. For example, this can occur at a massive scale as shown by the eruption of Mt. Pinatubo (Philippines) in 1991, when the volcanic column ruptured the tropopause at an altitude of $\sim 17 \mathrm{~km}$, introducing $\sim 20 \mathrm{Mt}$ of $\mathrm{SO}_{2}$ to the stratosphere (Oppenheimer, 2004). On the other hand, volcanic activity also releases huge amounts of metals into the atmosphere via quiescent degassing. For example, volcanic emanation estimates for different metals give figures in the order of $\left(\mathrm{Mg} \mathrm{yr}^{-1}\right)$ : 1000-2200 (Cu), 4800-8500 (Zn), 900$4100(\mathrm{~Pb}), 400(\mathrm{Cd})$, and 112-700 $(\mathrm{Hg})$ (Nriagu and Becker, 2003; Pyle and Mather, 2003; Oppenheimer, 2004). In the case of mercury, a highly volatile element, quiescent degassing would account for $10 \%$ of the yearly estimated flux, small eruptions may contribute with about $75 \%$ of the total, whereas those of catastrophic character would overwhelm the atmospheric budget of the element (Pyle and Mather, 2003). Thus, the least a magma chamber releases volatiles and metals to the atmosphere, the more enriched the hydrothermal fluids will be. In this way, the magmatic passage in the region from andesitic stratovolcanoes (strong outgassing) to dacitic intrusions (restricted venting) may indeed shed some light on: (1) why the older ( 13-10 Ma) hydrothermal episodes along the belt were barren; and 2) why the dome/dikes episodes gave rise to Au-Ag-(Cu-As) deposits ( 10-6 Ma).

\section{Conclusions}

Although mineral deposition is ruled by relatively well known physical-chemical processes, the framework in which the appropriate conditions are met in order to form large ore deposits comes from a rather fortuitous combination of geological events, in both time and space. This assertion is particularly valid in the case of formation of precious metal deposits. We cannot explain ore deposit formation in restricted terms, for example, magmatism or structure alone. On the contrary, in order to answer major questions such as "why here and not there" or "why in this particular time span and not before or after" we must analyze very carefully the many geological events that were occurring during ore deposit formation. After all, ore deposits are singularities, and as such, their study requires a broader view. Late Miocene time in northern Chile can be regarded as a crucial period when a number of favorable conditions coincided to generate a metallogenic belt such as that of El Indio. These conditions included ridge subduction, increased plate coupling, and a change in magmatism. Increased plate coupling would have resulted in reactivation of older NNE structures, along which the El Indio belt formed. Fault reactivation during ridge subduction may have been enhanced by coeval massive erosion-pediplain 
formation leading to the uplifting of structural blocks. Besides, the change in composition and style of magmatism, that is, from andesitic main edifices to dacitic dome or dike complexes, would have resulted in restricted venting of volatiles, which in turn would have led to enhanced retention of $\mathrm{SO}_{2}$ and metals, and therefore to formation of sulfur-, metal-rich hydrothermal solutions. This would explain why some deposits (e.g., El Indio) of the belt were so rich in sulfur and gave rise to $\mathrm{Cu}-\mathrm{Au}-\mathrm{As}-\mathrm{S}$ mineral parageneses of major economic importance.

\section{Acknowledgments}

This work was supported by the Spanish Agency for International Cooperation (AECI) and the Bureau of International Cooperation of the University of Castilla La Mancha. Additional funding was obtained from Grant 910386 (Universidad Complutense; Grupos de Investigación).

\section{REFERENCES}

Aguirre, L., and Egert, E., 1965, Cuadrángulo Quebrada Marquesa, Provincia de Coquimbo: Santiago, Chile, Instituto de Investigaciones Geológicas (Chile), escala 1:50,000, $92 \mathrm{p}$.

Araneda, R., 1985, Nuevos aportes al conocimiento de la geología de El Indio, yacimiento de oro, plata y cobre. Coquimbo, Chile: Revista Minerales, v. 168, p. 27-39.

Bissig, T., Clark, A. H., Lee, J. K. W., and Hodgson, C. J., 2002a, Miocene landscape evolution and geomorphologic controls on epithermal processes in the El IndioPascua Au-Ag-Cu belt, Chile and Argentina: Economic Geology, v. 97, p. 971-996.

Bissig, T., Clark, A. H., and Lee, J. K. W., 2002b, Cerro de Vidrio rhyolitic dome: Evidence for Late Pliocene volcanism in the central Andean flat-slab region, Lama-Veladero district, $29^{\circ} 20^{\prime} \mathrm{S}$, San Juan province, Argentina: Journal of South American Earth Sciences, v. 15, p. $571-576$.

Boris, R., 1985, Geología y yacimientos del distrito Talcuna, IV Región de Coquimbo: Revista Geológica de Chile, v. 25-26, p. 57-75.

Cande, S. C., and Leslie, R. B., 1986, Late Cenozoic tectonics of the southern Chile trench: Journal of Geophysical Research, v. 91, p. 471-496.

Chouinard, A., Williams-Jones, A. E., Leonardson, R. W., Hodgson, C. J., Silva, P., Téllez, C., Vega, J., and Rojas, F., 2005, Geology and genesis of the multistage high-sulfidation epithermal Pascua Au-Ag-Cu deposit, Chile and Argentina: Economic Geology, v. 100, p. 463-490.
Higueras, P., Oyarzun, R., Oyarzún, J., Maturana, H., Lillo, J., and Morata, D., 2004, Environmental assessment of copper-gold-mercury mining in the Andacollo and Punitaqui districts, northern Chile: Applied Geochemistry, v. 19, p. 1855-1864.

Kay, S. M., and Mpodozis, C., 2002, Magmatism as a probe to the Neogene shallowing of the Nazca plate beneath the modern Chilean flat-slab: Journal of South American Earth Sciences, v. 15, p. 39-57.

Le Roux, J. P., Olivares, D. M., Nielsen, S. N., Smith, N. D., Middleton, H., Fenner, J., and Ishman, S., 2006, Bay sedimentation as controlled by regional crustal behaviour, local tectonics, and eustatic sea-level changes: Coquimbo Formation (Miocene-Pliocene), Bay of Tongoy, central Chile: Sedimentary Geology, v. 184, p. 133-153.

MacMillan, I., Gans, P. B., and Alvarado, G., 2004, Middle Miocene to present plate tectonic history of the southern Central American volcanic arc: Tectonophysics, v. 392, p. 325-348.

Maksaev, V., Moscoso, R., Mpodozis, C., and Nasi, C., 1984, Las unidades volcánicas y plutónicas del Cenozoico Superior en la alta cordillera del Norte Chico $\left(29^{\circ}-31^{\circ} \mathrm{S}\right)$ : Geología, alteración hidrotermal y mineralización: Revista Geológica de Chile, v. 21, p. 11-51.

Matsumoto, A., and Hinkley, T. K., 2001, Trace metal suites in Antarctic pre-industrial ice are consistent with emissions from quiescent degassing of volcanoes worldwide: Earth and Planetary Science Letters, v. 186, p. $33-43$.

Nriagu, J., and Becker, C., 2003, Volcanic emissions of mercury to the atmosphere: Global and regional inventories: Science of the Total Environment, v. 304, p. 312.

Oppenheimer, C., 2004, Volcanic degassing, in Rudnick, R. L., ed., Treatise on geochemistry, Volume 3 (The Crust): Amsterdam, The Netherlands: Elsevier, p. 123-166.

Oyarzun, R., Lillo, J., Oyarzún, J., Higueras, P., and Maturana, H., 2006, Strong metal anomalies in stream sediments from semiarid watersheds in northern Chile: When geological and structural analyses contribute to understanding environmental disturbances: International Geology Review, v. 48, p. 1133-1144.

Oyarzun, R., Lillo, J., Sánchez-Hernández, J. C., and Higueras, P., 2005, Pre-industrial metal anomalies in ice cores: A simplified reassessment of windborne soil dust contribution and volcanic activity during the last glaciation: International Geology Review, v. 47, p. 1120-1130.

Oyarzun, R., Márquez, A., Lillo, J., López, I., and Rivera, S., 2001, Giant versus small porphyry copper deposits of Cenozoic age in northern Chile: Adakitic versus normal calc-alkaline magmatism: Mineralium Deposita, v. 36, p. 794-798.

Oyarzun, R., Ortega, L., Sierra, J., Lunar, R., and Oyarzún, J., 1996, The manto-type gold deposits of Andacollo 
(Chile) revisited: A model based on fluid inclusion and geological evidence: Economic Geology, v. 91, p. 1298-1309.

Oyarzun, R., Ortega, L., Sierra, J., Lunar, R., and Oyarzún, J., 1998, Cu, Mn, and Ag mineralization in the Quebrada Marquesa Quadrangle, Chile: The Talcuna and Arqueros districts: Mineralium Deposita, v. 33, p. 547-559.

Oyarzun, R., Oyarzún, J., Ménard, J. J., and Lillo, J., 2003, The Cretaceous iron belt of northern Chile: Role of oceanic plates, a superplume event, and a major shear zone: Mineralium Deposita, v. 38, p. 640-646.

Passchier, C. W., and Trouw, R. A. J., 1998, Microtectonics: Berlin, Germany, Springer, 289 p.

Pasteris, J. D., 1996, Mount Pinatubo volcano and "negative" porphyry copper deposits: Geology, v. 24, 10751078.

Pyle, D. M., and Mather, T. A., 2003, The importance of volcanic emissions for the global atmospheric mercury cycle: Atmospheric Environment, v. 37, p. 5115-5124.

Rampino, M. R., and Self, S., 1992, Volcanic winter and accelerated glaciation following the Toba super-eruption: Nature, v. 359, p. 50-52.

Richards, J. P., 2000, Lineaments revisited: SEG Newsletter, v. 42, p. 13-20.

Rivano, S., and Sepúlveda, P., 1991, Hoja Illapel, Carta Geológica de Chile 69, escala 1: 250,000: Santiago, Chile, SERNAGEOMIN (Servicio Nacional de Geología y Minería), 132 p.
Salfitty, J. A., 1985, Lineamientos transversales al rumbo andino en el noroeste argentino: 4th Chilean Geologic Congress: Concepción, Chile, University of Concepción Press, v. 2, p. 119-137.

Siddeley, G., and Araneda, R., 1986, The El Indio-Tambo gold deposits, in Macdonald, A. J., ed., Gold '86, International Symposium on the Geology of Gold: Amsterdam, The Netherlands, Balkema, p. 3-22.

Tebbens, S. F., and Cande, S. C., 1997, Southeast Pacific tectonic evolution from early Oligocene to present: Journal of Geophysical Research, v. 102, p. 12,06112,084 .

Tripp, G. I., and Vearncombe, J. R., 2004, Fault/fracture density and mineralization: A contouring method for targeting in gold exploration: Journal of Structural Geology, v. 26, p. 1087-1108.

Yáñez, G., Cembrano, J., Pardo, M., Ranero, C., and Selles, D., 2002, The Challenger-Juan FernándezMaipo major tectonic transition of the Nazca-Andean subduction system at $33-34^{\circ} \mathrm{S}$ : Geodynamic evidence and implications: Journal of South American Earth Sciences, v. 15, p. 23-38.

Yang, K., and Scott, S. D., 2005, Vigorous exsolution of volatiles in the magma chamber beneath a hydrothermal system on the modern sea floor of the Eastern Manus back-arc basin, western Pacific: Evidence from melt inclusions: Economic Geology, v. 100, p. 10851096. 